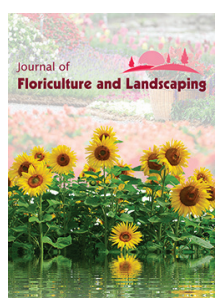

ISSN: $2663-6050$

Received: March 28, 2018 Accepted: May 11, 2018 Published: May 19, 2018

*Corresponding Author:

Rameshkumar

Email: rameshflora@yahoo.com

\section{Studies on vertical garden system: A new landscape concept for urban living space}

\author{
S. Rameshkumar \\ Department of Horticulture, Faculty of Agriculture, Annamalai University, Annamalai Nagar 608 o02, Tamil Nadu, India
}

\begin{abstract}
Vertical gardens are becoming a common component in contemporary garden designs at urban living space because of shrinking land spaces. Successful growing of plants in vertical garden systems depends up on growing container, plants chosen, growing media, etc. Hence a study was carried out in the Department of Horticulture, Annamalai University, with the objectives to study the influence of Coir pith, Stockosorb and Geohumus as components of growing media along with FYM, Vermicompost and Leaf mould compost on growth and performance of ornamental plants for establishment of vertical garden and to study the performance of ornamental plants Viz., Philodendron erubescens Cv. 'Gold', Chlorophytum comosum Cv. 'Variegatum' and Polyscias fruticosa plants in wooden containers for establishment of vertical garden. The experiment was laid out in Completely Randomized Design in wooden containers, with ten treatment combinations of various growing media mixtures comprising red soil, river sand as basic components in combination with organic manures (FYM, vermicompost, leaf mould compost, coir pith) and hydrogels (Stocksorb and Geohumus). The plant growth characters and ornamental value index were observed. Among the three ornamental plants used, Polyscias fruticosa and Philodendron erubescens are performed better as ornamental plants in vertical garden system with the growing media of Red soil: River sand: Vermicompost @ 1:1:1/2 + Stockosorb(25g).
\end{abstract}

KEYWORDS: Philodendron erubescens, Chlorophytum comosum, Polyscias fruticosa, vertical garden

\section{INTRODUCTION}

Climate change has made the concept of changing our living ambiance very important to make quality living. Vertical gardens are the tools that can be employed to enhance the quality of air, solve the heat problems in urban areas and the same time improve aesthetics of our living places. Vertical gardens are becoming a common component in contemporary garden designs because of shrinking land spaces and multiplying highrises with scanty space available for gardening. Though, the idea of vertical garden began in $600 \mathrm{BC}$ from Hanging Gardens of Babylon and then it was not used often by successive gardeners like Persians, Mughals, Europeans and others. Today, with the rapid growth of industrial cities and for want of horizontal space for other utilities this concept was picked up rapidly by contemporary gardeners. Vertical gardens are living walls which are covered with vegetation. Successful growing of plants in vertical garden systems depends up on design of the vertical garden system, growing container, irrigation arrangement, plants chosen, growing media, etc. The shade loving indoor ornamental plants like Philodendron sp., Asparagus sp., Chlorophytum sp., Polyscias fruticosa, Aglaonema, Rhoeo spathacea, Sempervivum, etc. are considered as suitable options based on their ornamental features, however, studies revealing the suitability of plants for vertical garden system is lacking in India. The members of Araceae, Asparagaceae and Araliaceae families viz., Philodendron erubescens, Chlorophytum comosum and Polyscias fruticosa respectively are used in this study by virtue of their textural properties and easy adoptability in tropical to sub tropical conditions.

The growing medium is the most important component that decides the success of a vertical garden system. Increasing cost of these media components and shortage of the mineral media like peat, perlite and vermiculite are the reasons to find suitable alternative components from organic manures and hydrogel compounds for plant growing containers used in vertical garden system. Further, restricted volume of media and competition due to higher planting density may cause a confined root system. In due course of maintenance this system needs heavy applications of fertilizer and water to maintain proper plant growth. In line with the above facts a study was carried out with the objectives to study the influence of Coir pith, Stockosorb and Geohumus as components of growing media along with FYM, Vermicompost and Leaf mould compost on growth and performance of ornamental plants in wooden containers for 
establishment of vertical garden and to standardize the growing media mixtures suitable for establishment of vertical garden.

\section{MATERIAL AND METHODS}

In this experiment living wall system of vertical garden was established with fabricated iron frames to hold the planter boxes made in country wood in alternate rows. The wooden box was fabricated with two slits in the front side to accommodate two rows of plants to cover the sides of the wall. On top of the planter box another row of ornamental plant was planted to cover the gap existing in alternate rows of the vertical frame. The vertical garden system made of wooden box container $(90 \mathrm{~cm} \times 30 \mathrm{~cm} \times 30 \mathrm{~cm})$ was designed to grow 24 numbers of plants that is essential to establish a green cover over the surface of container (Plate 1). The experiment was laid out in Completely Randomized Design, replicated thrice with ten treatment combinations of various growing media mixtures comprising red soil, river sand as basic components in combination with organic manures (FYM, vermicompost, leaf mould compost, coir pith) and hydrogels (Stocksorb and Geohumus). Control treatment was maintained with normal soil. The plant growth characters like days taken for establishment, plant height, number of shoots, shoot girth, number of leaves per plant, leaf area, biomass production, chlorophyll content and ornamental value index were observed. Ornamental value index was given to the plants in each treatment by visually assessing the ornamental features of the plants in terms of their foliage colour, compactness, texture, height and overall look. Ten point Headonic scoring technique was adopted to grade the ornamental value of the plants.

\begin{tabular}{lll}
\hline Grade No. & Ornamental features & Grade point \\
\hline G1 & $\begin{array}{l}\text { Establishment: Shoots and leaves } \\
\text { growing and stretching against }\end{array}$ & 10,9 to 1 and 0 \\
geotropic movement. & \\
G2 & $\begin{array}{l}\text { Compactness : From densely } \\
\text { packed foliage to space loose } \\
\text { fronds and dried up plant }\end{array}$ & 10,9 to 1 and 0 \\
G3 & $\begin{array}{l}\text { Number of stems per poly bag: } \\
\text { from } 10 \text { to } 3 \text { and dried up plant }\end{array}$ & 10,9 to 1 and 0 \\
G4 & $\begin{array}{l}\text { Texture : from fine to course and } \\
\text { dried up plant }\end{array}$ & 10,9 to 1 and 0 \\
G5 & $\begin{array}{l}\text { Freshness of plants: from firm } \\
\text { turgid to flaccid condition and } \\
\text { dried leaves }\end{array}$ & 10,9 to 1 and 0 \\
G6 & Overall out look & 10,9 to 1 and 0 \\
\hline
\end{tabular}

Ornamental valueindex $=\frac{\mathrm{GP} 1+\mathrm{GP} 2+\mathrm{GP} 3+\mathrm{GP} 4+\mathrm{GP} 5+\mathrm{GP} 5}{6}$

The statistical analysis of data was done by adopting the standard statistical procedure given by Panse and Sukhatme (1967).

\section{RESULT AND DISCUSSION}

Results of the present experiment envisaged that the growth parameters viz., days taken for establishment, plant height, number of shoots/branches, shoot girth, number of leaves plant ${ }^{-1}$

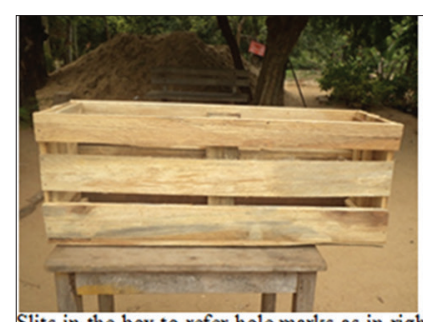

Slits in the box to refer hole marks as in right side picture

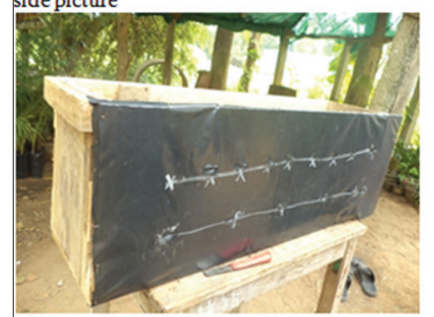

Making planting holes out side

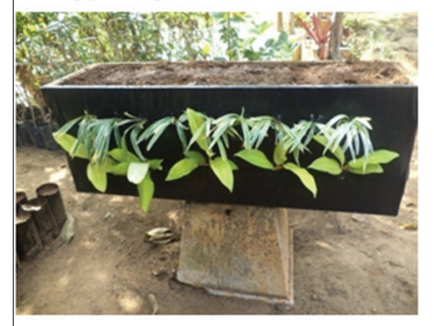

Planting

Plate 1: Fabrication of planter boxes for vertical garden system

and leaf area were significantly increased due to the addition of organic growing media components and hydrogels (Table 1). In general, addition of hydrogels viz., Stockosorb and Geohumus performed better than the coir pith in growing media as a component. Among the organic components used in media, vermicompost performed better in terms of all the growth parameters of the ornamental plants. In all the three ornamental plants, $\mathrm{T}_{9}[$ Red soil + River sand + Vermicompost $(1: 1: 1 / 2)+$ Stockosorb $(25 \mathrm{~g})]$ has exhibited greater influence in terms of all the growth parameters with quicker establishment of plants. This was followed by $\mathrm{T}_{10}$ [Red soil + River sand + Vermicompost $(1: 1: 1 / 2)+$ Geohumus (25g)]. Enhancement of growth in all the three ornamental plants due to above mentioned two growing media combinations might be attributed to the addition of vermicompost and hyogels particularly Stocksorb and Geohumus in addition to normal components of a growing media like red soil and river sand. Enhancement in the growth attributes due to vermicompost in the present research is in line with the reports of (Rajamanickam et al. 2008) who revealed enhanced growth parameters in plants grown in potting mixture, treated with vermicompost. The report of (Golchin et al. 2006) in pistachio nut seedlings was also in conformity of the present research. Further, the enhanced performance of ornamental plants grown in media containing vermicompost could be attributed by the fact that vermicompost contains major and minor nutrients for the plants in available forms besides enzymes, antibiotics, vitamins, beneficial microorganisms and other plant growth hormones and have definite advantage over other organic; manures in respect of growth (Meerabai and Raj, 2001). 


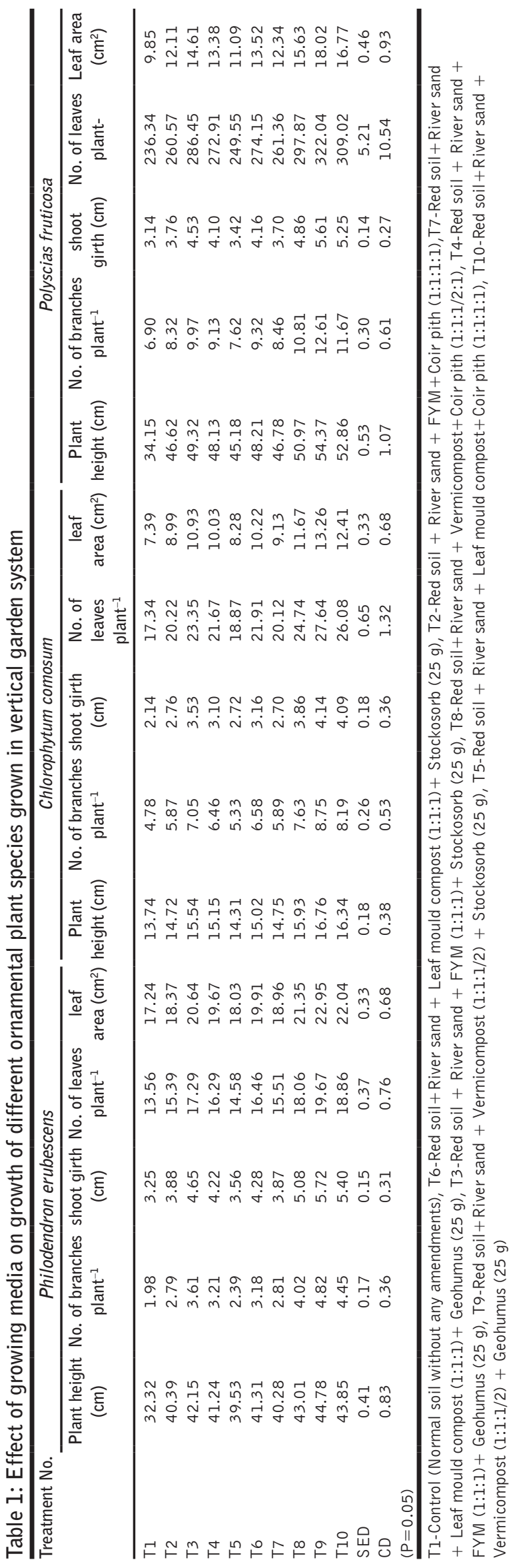

The positive influence of hydrogel compounds on ornamental plants in the vertical plant growing containers might be due to the facts that hydrogels maintain a conductive soil environment. The highly cross-linked polyacrylamide hydrogels can absorb and hold up to 400 times their weight of water (Bouranis et al., 1995), which aid faster establishment of ornamental plants in containers where media volume is restricted. As reported by Sarvas (2003); Abedi-Koupai and Asadkazemi (2006) in different experiments on the effects of hydrogels on plant growth, the present experiment also indicated increased growth attributes like total bio mass under limited water availability.

The quality parameters of the ornamental plants grown in vertical garden containers can be determined by assessing the total chlorophyll content and ornamental value index. These values of all the three ornamental plants were significantly varied due to different combinations of growing media mixtures (Table 2). The highest total chlorophyll content $\left(2.73 \mathrm{mg} \mathrm{g}^{-1}, 2.62 \mathrm{mg} \mathrm{g}^{-1}\right.$ and $2.91 \mathrm{mg} \mathrm{g}^{-1}$ respectively for Philodendron sp, Chlorophytum sp and Polyscias sp) and ornamental value index $(8.54,7.30$ and 9.56 respectively for Philodendron sp, Chlorophytum sp and Polyscias sp) were observed in the plants grown in $\mathrm{T}_{9}$ [Red soil + River sand + Vermicompost $(1: 1: 1 / 2)+$ Stockosorb $(25 \mathrm{~g})]$. The next best treatment in terms of the results obtained in these parameters was $\mathrm{T}_{10}[$ Red soil + River sand + Vermicompost (1:1:1/2) + Geohumus (25g)].

The best results obtained in these quality parameters might be attributed to the enhanced growth in terms of plant height, number of shoot plant ${ }^{-1}$, number of leaves plant ${ }^{-1}$, leaf area and total biomass plant ${ }^{-1}$. Best performance of all the three ornamental plants with highest values in quality parameters in the present study due to addition of organic growing components like vermicompost and leaf mould compost is in accordance with the reports of Meerabai and Raj (2001) in ornamental plants and Hidalgo and Harkess (2002) in poinsettia. Enhancement in the quality parameters of the ornamental plants due to addition of hydrogels like Stocksorb and Geohumus might be attributed to the enhanced water availability in the medium which increased the turgidity and freshness of the foliage (Bouranis et al., 1995).

By considering the mean performance of all the three ornamental plants (Table 3) it is concluded that Polyscias fruticosa and Philodendron erubescens plants can be used as ornamental plants for establishment of vertical garden system. To use Chlorophytum comosum as a component in this system a modification in the planting position is needed. The physiochemical properties of the growing media mixtures and growth attributes and quality parameters of the three ornamental plants evinced that media combinations of Red soil + River sand + Vermicompost $(1: 1: 1 / 2)+$ Stockosorb $\left(\mathrm{T}_{9}\right)$ or Red soil + River sand + Vermicompost (1:1:1/2) + Geohmus $\left(\mathrm{T}_{10}\right)$ can be used to establish the above ornamental plants in wooden containers of a vertical garden system fabricated in iron frames. 
Table 2: Effect of growing media on growth of different ornamental plant species grown in vertical garden system

\begin{tabular}{|c|c|c|c|c|c|c|c|c|c|}
\hline \multirow{2}{*}{$\begin{array}{l}\text { Treatment } \\
\text { No. }\end{array}$} & \multicolumn{3}{|c|}{ Philodendron erubescens } & \multicolumn{3}{|c|}{ Chlorophytum comosum } & \multicolumn{3}{|c|}{ Polyscias fruticosa } \\
\hline & $\begin{array}{l}\text { Total biomass } \\
\text { g plant }^{-1}\end{array}$ & $\begin{array}{c}\text { Chlorophyll } \\
\text { content } \\
\left(\mathrm{mg} \mathrm{g}^{-1}\right) \\
\end{array}$ & $\begin{array}{l}\text { Ornamental } \\
\text { value index }\end{array}$ & $\begin{array}{l}\text { Total biomass } \mathrm{g} \\
\text { plant }^{-1}\end{array}$ & $\begin{array}{c}\text { Chlorophyll } \\
\text { content } \\
\left(\mathrm{mg} \mathrm{g}^{-1}\right)\end{array}$ & $\begin{array}{l}\text { Ornamental } \\
\text { value index }\end{array}$ & $\begin{array}{c}\text { Total } \\
\text { biomass } \\
\text { g plant }^{-1}\end{array}$ & $\begin{array}{c}\text { Chlorophyll } \\
\text { content } \\
\left(\mathrm{mg} \mathrm{g}^{-1}\right) \\
\end{array}$ & $\begin{array}{l}\text { Ornamental } \\
\text { value index }\end{array}$ \\
\hline $\mathrm{Tl}$ & 162.23 & 1.53 & 5.39 & 41.31 & 1.49 & 4.03 & 282.06 & 1.65 & 6.12 \\
\hline $\mathrm{T} 2$ & 185.02 & 2.34 & 7.08 & 48.00 & 2.22 & 5.61 & 336.70 & 2.53 & 8.39 \\
\hline T3 & 215.10 & 1.98 & 7.69 & 55.39 & 1.94 & 6.25 & 393.86 & 2.20 & 8.93 \\
\hline T4 & 199.45 & 2.41 & 7.36 & 51.75 & 2.31 & 5.92 & 366.41 & 2.42 & 8.66 \\
\hline T5 & 174.15 & 2.65 & 6.82 & 44.98 & 2.54 & 5.35 & 312.15 & 2.83 & 8.13 \\
\hline T6 & 203.68 & 2.36 & 7.43 & 52.33 & 2.24 & 5.96 & 371.44 & 2.50 & 8.70 \\
\hline T7 & 188.64 & 2.57 & 7.12 & 48.38 & 2.43 & 5.66 & 343.36 & 2.72 & 8.42 \\
\hline T8 & 226.25 & 2.45 & 7.96 & 58.56 & 2.33 & 6.51 & 359.50 & 2.65 & 9.19 \\
\hline T9 & 249.35 & 2.73 & 8.54 & 64.09 & 2.62 & 7.30 & 570.20 & 2.91 & 9.56 \\
\hline T10 & 238.14 & 2.58 & 8.25 & 61.64 & 2.46 & 6.82 & 417.56 & 2.77 & 9.46 \\
\hline SED & 4.70 & 0.08 & 0.11 & 1.42 & 0.09 & 0.12 & 9.56 & 0.08 & 0.10 \\
\hline $\begin{array}{l}C D \\
(P=0.05)\end{array}$ & 9.51 & 0.17 & 0.22 & 2.88 & 0.18 & 0.24 & 19.34 & 0.17 & 0.20 \\
\hline
\end{tabular}

Table 3: Mean Performance of Ornamental plants grown in wooden containers of vertical garden system

\begin{tabular}{lccc}
\hline Ornamental features and growth parameters & Philodendron erubescens & Chlorophytum comosum & Polyscias fruticosa \\
\hline Planting position in planter box & Side slit bottom layer (Horizontal) & Side slit top layer (Horizontal) & Top side (Normal planting) \\
Plant Texture & Coarse & Fine & Medium coarse \\
Days Taken for Establishment & 17.77 & 25.33 & 9.27 \\
Total biomass $\left(\right.$ g plant $\mathrm{H}^{-1}$ ) & 204.20 & 52.64 & 375.32 \\
Dry matter Production $\left(\mathrm{g} \mathrm{plant}^{-1}\right.$ ) & 40.65 & 10.71 & 74.04 \\
Chlorophyll content $\left(\mathrm{mg}^{-1}\right.$ ) & 2.36 & 2.25 & 2.51 \\
Ornamental value index & 7.36 & 5.94 & 8.55 \\
Performance ranking & II & III & I \\
\hline
\end{tabular}

\section{REFERENCES}

Abedi-Koupai, J. and Asadkazemi, J., 2006. Effects of a Hydrophilic Polymer on the Field Performance of an Ornamental Plant (Cupressus arizonica) under Reduced Irrigation Regimes, Iranian Polym. J., 15 (9): 715 -725.

Bouranis, D. L., A. G. Theodoropoulus, J. B. Drossopoulus. 1995. Designing Synthetic Polymers as Soil Conditioners, Commun. Soil Sci. Plant Anal.,26: $1455-1480$.

Golchin, A., Nadi, M. and Mozaffari, V. 2006. The effects of vermicompost produced from various organic solid wastes on growth of pistachio seedlings. Acta Hort., 726: 301-305.

Hidalgo, P.R. and R.L. Harkess. 2002. Earthworm castings as a substrate for poinsettia production. Hort. Science, 37(2): 304 - 308.

Ingram, D. L., R. W. Henley, and T. H. Yeager. 2003. Growth media for container grown ornamental plants. Environmental Horticulture
Department, Florida Cooperative Extension Service, Inst. of Food and Agri. Sci., University of Florida, BUL 241.

Meerabai, M. and Raj. 2001. Biofarming in vegetables. Kisan World, 28(4): 15

Panse, V.G. and Sukhatme, P.V. 1967. Statistical methods for agricultural workers, ICAR, New Delhi.

Rajamanickam, C., Balasubramaniam, S. and Natarajan, S. 2008. Studies on nursery management in papaya (Carica papaya L.) cv. Co2, proceedings of second international symposium on papaya, pp. 74.

Sahin, U., and O. Anapali. 2006. Addition of pumice affects physical properties of soil used for container grown plants. Agric. Conspec. Sci. 71:59-64.

Sarvas, R., P. Pavlenda, E. Takacova. 2007. Effect of hydrogel application on survival and growth of pine seedlings in reclamations. J. Forest Sci., 53, (5): 204-209. 